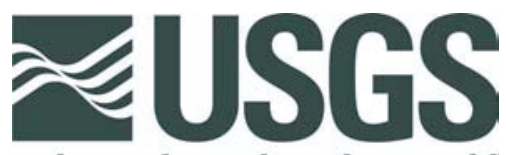

science for a changing world

\title{
U.S. Geological Survey 2002 Petroleum Resource Assessment of the National Petroleum Reserve in Alaska (NPRA): Play Maps and Technically Recoverable Resource Estimates
}

\author{
By Kenneth J. Bird ${ }^{1}$ and David W. Houseknecht ${ }^{2}$
}

Open-File Report 02-207 2002

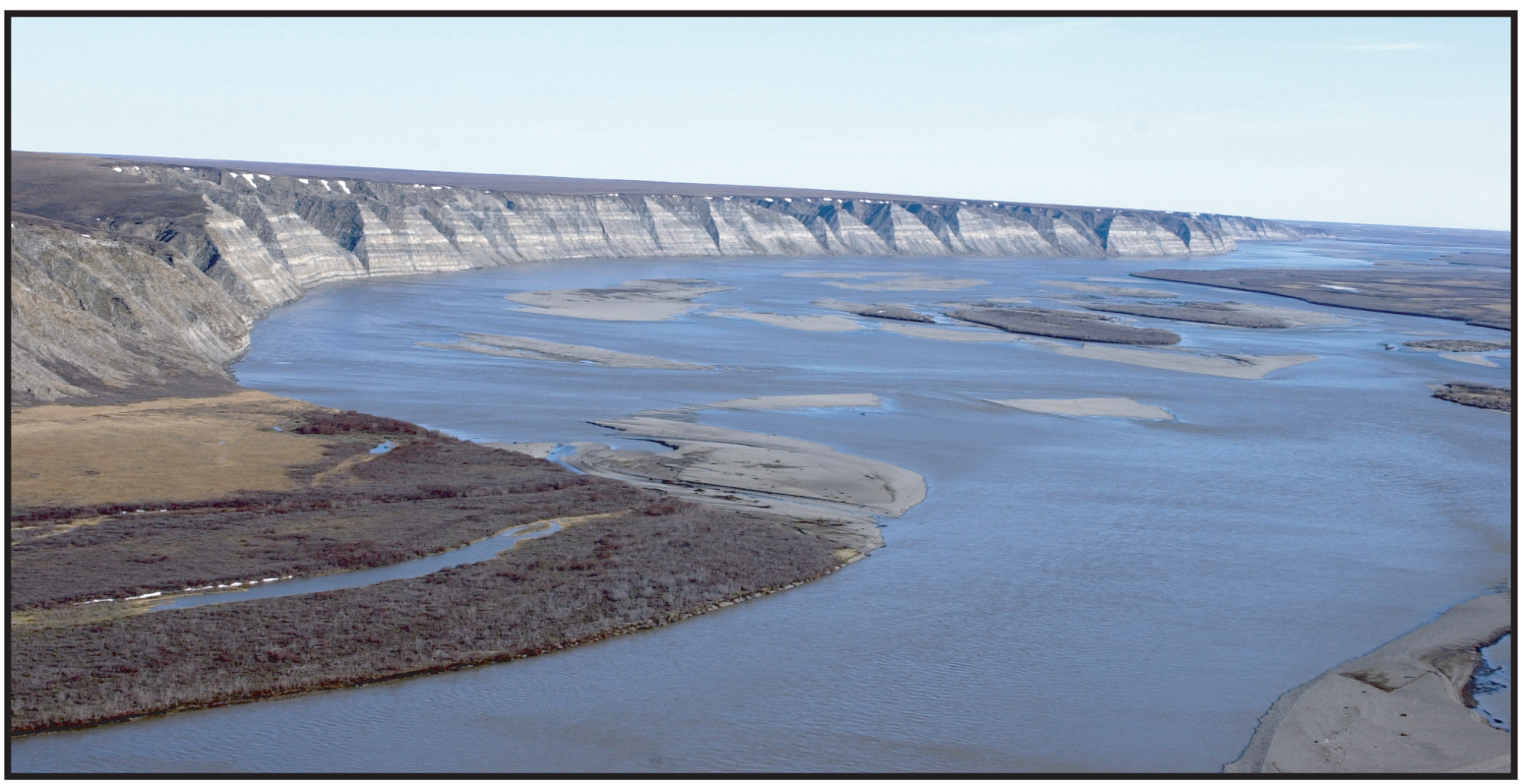

Manuscript approved, May 14, 2002

This report is preliminary and has not been reviewed for conformity with U.S. Geological Survey editorial standards or with the North American Stratigraphic Code. Any use of trade, firm, or product names is for descriptive purposes only and does not imply endorsement by the U.S. Government.

U.S. DEPARTMENT OF THE INTERIOR

U.S. GEOLOGICAL SURVEY

${ }^{1}$ U.S. Geological Survey, Menlo Park, CA 94025.

${ }^{2}$ U.S. Geological Survey, Reston, VA 20192. 


\section{CONTENTS}

Introduction and Summary

References Cited

Table 1. Oil and nonassociated gas resources for each of the 24 plays.

Figure 1. Stratigraphic column for the NPRA

Figure 2. Map showing the areal extent of the Brookian Topset Play

Figure 3. Map showing the areal extent of the Brookian Clinoform Plays

Figure 4. Map showing the areal extent of the Beaufortian Cretaceous Topset Plays

Figure 5. Map showing the areal extent of the Beaufortian Upper Jurassic Topset Plays

Figure 6. Map showing the areal extent of the Beaufortian Lower Jurassic Topset Play

Figure 7. Map showing the areal extent of the Beaufortian Clinoform Play

Figure 8. Map showing the areal extent of the Brookian Topset Structural Play

Figure 9. Map showing the areal extent of the Brookian Torok Structural Play

Figure 10. Map showing the areal extent of the Thrust Belt and Ellesmerian Structural Plays

Figure 11. Map showing the areal extent of the Ellesmerian Ivishak Play

Figure 12. Map showing the areal extent of the Ellesmerian Echooka Plays

Figure 13. Map showing the areal extent of the Ellesmerian Lisburne Plays

Figure 14. Map showing the areal extent of the Ellesmerian Endicott Basins Plays 


\section{Introduction and Summary}

This report provides a summary of the estimated volume of technically recoverable undiscovered oil and nonassociated gas resources for each of the 24 plays evaluated in the U.S. Geological Survey 2002 petroleum resource assessment of the NPRA (Bird and Houseknecht, 2002). It also provides a set of illustrations showing the stratigraphic and geographic location of each play. Additional details of this assessment will follow in later publications.

Table 1 shows the undiscovered, technically recoverable oil and nonassociated gas resources estimated to occur in each of 24 plays evaluated in this assessment. The assessment method yields a probablistic range of estimates for each play. Here, we report petroleum volumes representing the 95th- and 5thpercentile estimates, the mean estimate, and the standard deviation. Volumes of petroleum associated with the 95th- and 5th-percentiles are considered reasonable estimates of minimum and maximum volumes that may be present, and the mean is the average or expected value. Volumes of undiscovered, associated gas and natural gas liquids were also evaluated and will be reported in later publications.

A stratigraphic column (figure 1) provides a summary of ages, names, and rock types present in the NPRA and the stratigraphic position of the 24 petroleum plays evaluated in the 2002 assessment.

A set of maps (figures 2-14) shows the areal extent of each of the plays in the NPRA study area, which includes Federal and Native onshore land and adjacent State offshore areas.

Documentation of the assessment will appear in a later publication. That publication will consist of separate chapters and will include details of the petroleum geology of the NPRA, play descriptions, assessment methodology including assessment forms, economic analysis, and other, related studies.

\section{References Cited}

Bird, K.J., and Houseknecht, D.W., 2002, U.S. Geological Survey 2002 petroleum resource assessment of the National Petroleum Reserve in Alaska (NPRA): U.S. Geological Survey Fact Sheet 045-02, 6 p. 
Table 1. Technically recoverable, undiscovered oil and nonassociated gas resources for each of the 24 plays evaluated in the 2002 NPRA assessment.

\begin{tabular}{|c|c|c|c|c|c|c|c|c|c|}
\hline \multirow{2}{*}{$\begin{array}{c}\text { Map } \\
\text { figure } \\
\text { no. }\end{array}$} & \multirow[t]{2}{*}{$\begin{array}{c}\text { Assessment Unit } \\
\text { (Plays) }\end{array}$} & \multicolumn{4}{|c|}{$\begin{array}{c}\text { Oil } \\
\text { (millions of barrels) }\end{array}$} & \multicolumn{4}{|c|}{$\begin{array}{l}\text { Nonassociated Gas } \\
\text { (billions of cubic feet) }\end{array}$} \\
\hline & & F95 & Mean & F05 & Std.Dev. & F95 & Mean & F05 & Std.Dev. \\
\hline & BROOKIAN STRATIGRAPHIC PLAYS & & & & & & & & \\
\hline 2 & Brookian Topset & 61 & 239 & 465 & 125 & 0 & 192 & 679 & 253 \\
\hline 3 & Brookian Clinoform North & 538 & 1306 & 2257 & 531 & 0 & 674 & 1969 & 660 \\
\hline 3 & Brookian Clinoform Central & 299 & 973 & 1849 & 477 & 1806 & 5405 & 10076 & 2535 \\
\hline 3 & Brookian Clinoform South-Shallow & 0 & 508 & 1254 & 389 & 0 & 2405 & 5809 & 1792 \\
\hline 3 & Brookian Clinoform South-Deep & 0 & 0 & 0 & 0 & 0 & 3788 & 8796 & 2843 \\
\hline 4 & $\begin{array}{l}\text { BEAUFORTIAN STRATIGRAPHIC PLAYS } \\
\text { Beaufortian Cretaceous Topset North }\end{array}$ & 0 & 103 & 239 & 75 & 0 & 405 & 1162 & 397 \\
\hline 4 & Beaufortian Cretaceous Topset South & 0 & 0 & 0 & 0 & 635 & 2130 & 4004 & 1029 \\
\hline 5 & Beaufortian Upper Jurassic Topset Northeast & 2744 & 5176 & 8086 & 1645 & 0 & 0 & 0 & 0 \\
\hline 5 & Beaufortian Upper Jurassic Topset Southeast & 0 & 0 & 0 & 0 & 2053 & 5137 & 9030 & 2148 \\
\hline 5 & Beaufortian Upper Jurassic Topset Northwest & 733 & 1859 & 3312 & 787 & 0 & 0 & 0 & 0 \\
\hline 5 & Beaufortian Upper Jurassic Topset Southwest & 0 & 0 & 0 & 0 & 2008 & 5220 & 9265 & 2261 \\
\hline 6 & Beaufortian Lower Jurassic Topset & 0 & 83 & 210 & 68 & 0 & 793 & 1915 & 612 \\
\hline 7 & Beaufortian Clinoform & 0 & 12 & 71 & 28 & 0 & 822 & 2180 & 719 \\
\hline & STRUCTURAL PLAYS & & & & & & & & \\
\hline 8 & Brookian Topset Structural & 0 & 137 & 654 & 269 & 4801 & 10606 & 18012 & 4072 \\
\hline 9 & Torok Structural & 0 & 35 & 222 & 101 & 0 & 17905 & 35012 & 10120 \\
\hline 10 & Ellesmerian Structural & 0 & 0 & 0 & 0 & 0 & 1990 & 5675 & 1920 \\
\hline 10 & Thrust Belt & 0 & 6 & 43 & 23 & 0 & 1521 & 4240 & 1473 \\
\hline & ELLESMERIAN STRATIGRAPHIC PLAYS & & & & & & & & \\
\hline 11 & Ellesmerian Ivishak & 0 & 84 & 243 & 81 & 0 & 106 & 565 & 211 \\
\hline 12 & Ellesmerian Echooka North & 0 & 7 & 0 & 41 & 0 & 7 & 0 & 78 \\
\hline 12 & Ellesmerian Echooka South & 0 & 0 & 0 & 0 & 0 & 505 & 2087 & 756 \\
\hline 13 & Ellesmerian Lisburne North & 0 & 29 & 181 & 79 & 0 & 22 & 0 & 146 \\
\hline 13 & Ellesmerian Lisburne South & 0 & 0 & 0 & 0 & 0 & 646 & 2732 & 982 \\
\hline 14 & Ellesmerian Endicott North & 0 & 3 & 0 & 17 & 0 & 1 & 0 & 21 \\
\hline 14 & Ellesmerian Endicott South & 0 & 0 & 0 & 0 & 0 & 1072 & 4816 & 1770 \\
\hline & Aggregated Totals & 6673 & 10558 & 15007 & 2546 & 40372 & 61351 & 85317 & 13714 \\
\hline
\end{tabular}


AGE

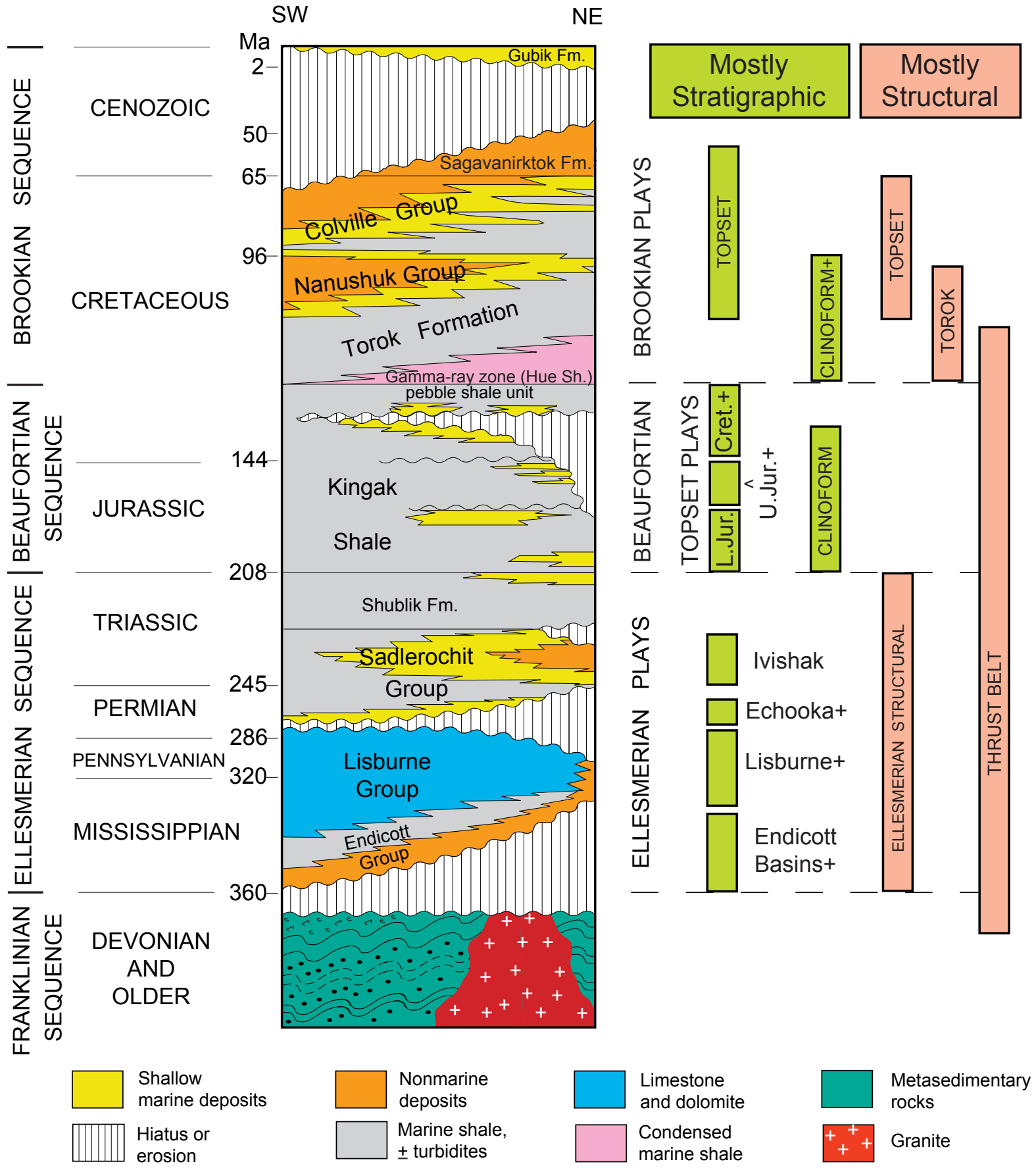

Figure 1. Stratigraphic column for the NPRA assessment area showing the stratigraphic position of the 24 plays evaluated in the 2002 USGS assessment. Six plays with a "+" symbol actually consist of two or more plays in different geographic areas, so the 14 plays indicated here represent all 24 plays listed in Table 1. 


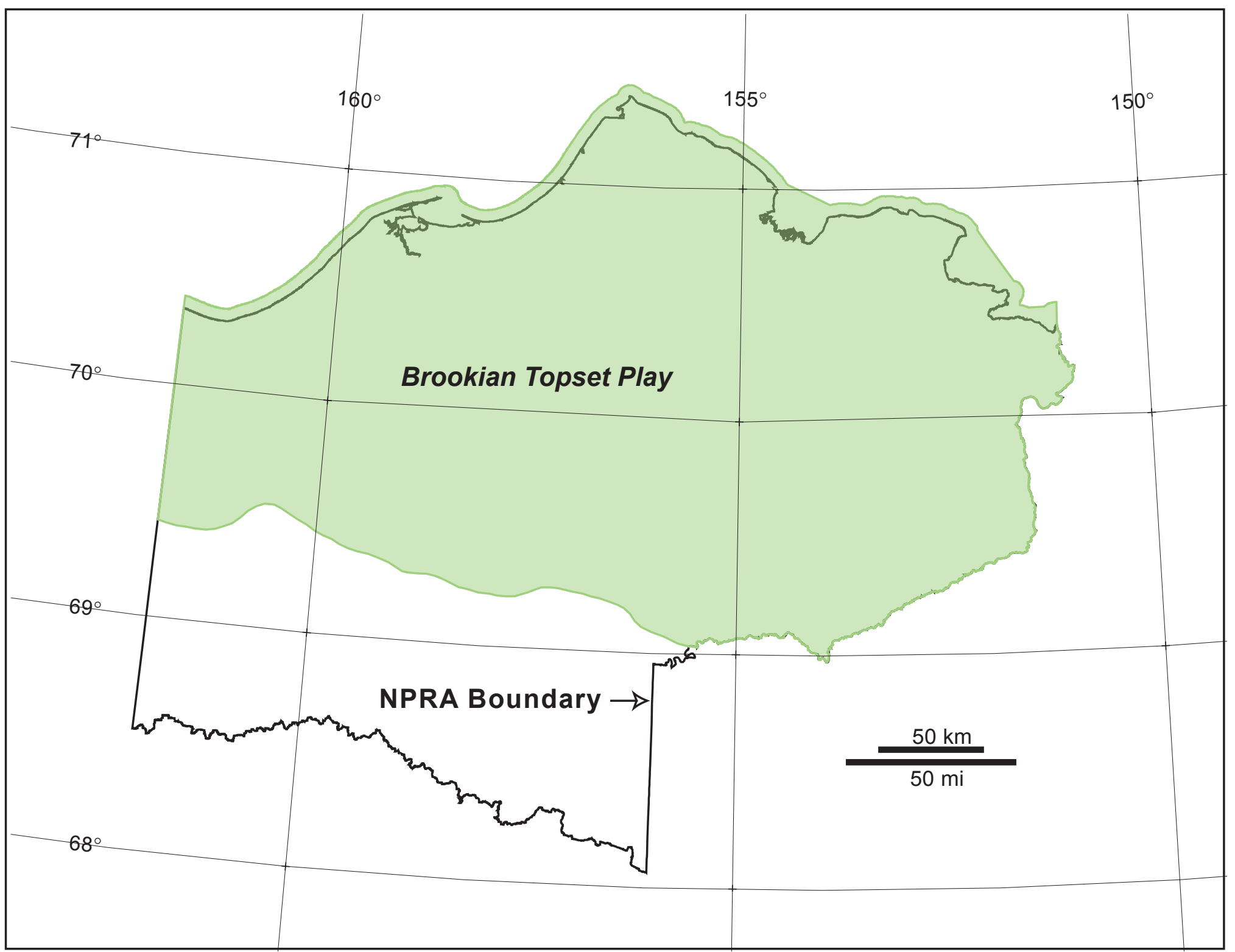

Figure 2. Map showing the areal extent of the Brookian Topset Play evaluated in the 2002 USGS petroleum resource assessment of the NPRA. 


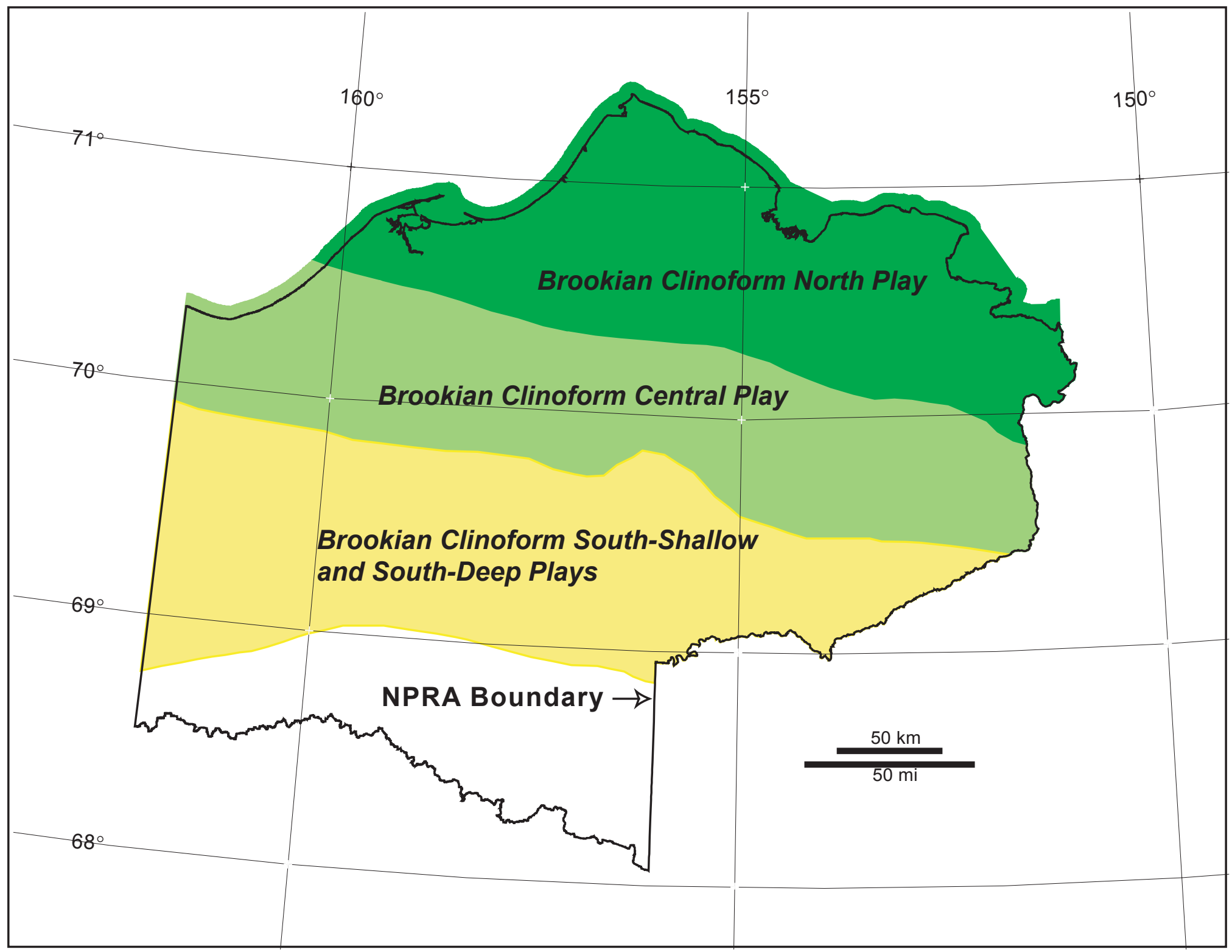

Figure 3. Map showing the areal extent of the four Brookian Clinoform Plays evaluated in the 2002 USGS petroleum resource assessment of the NPRA. 


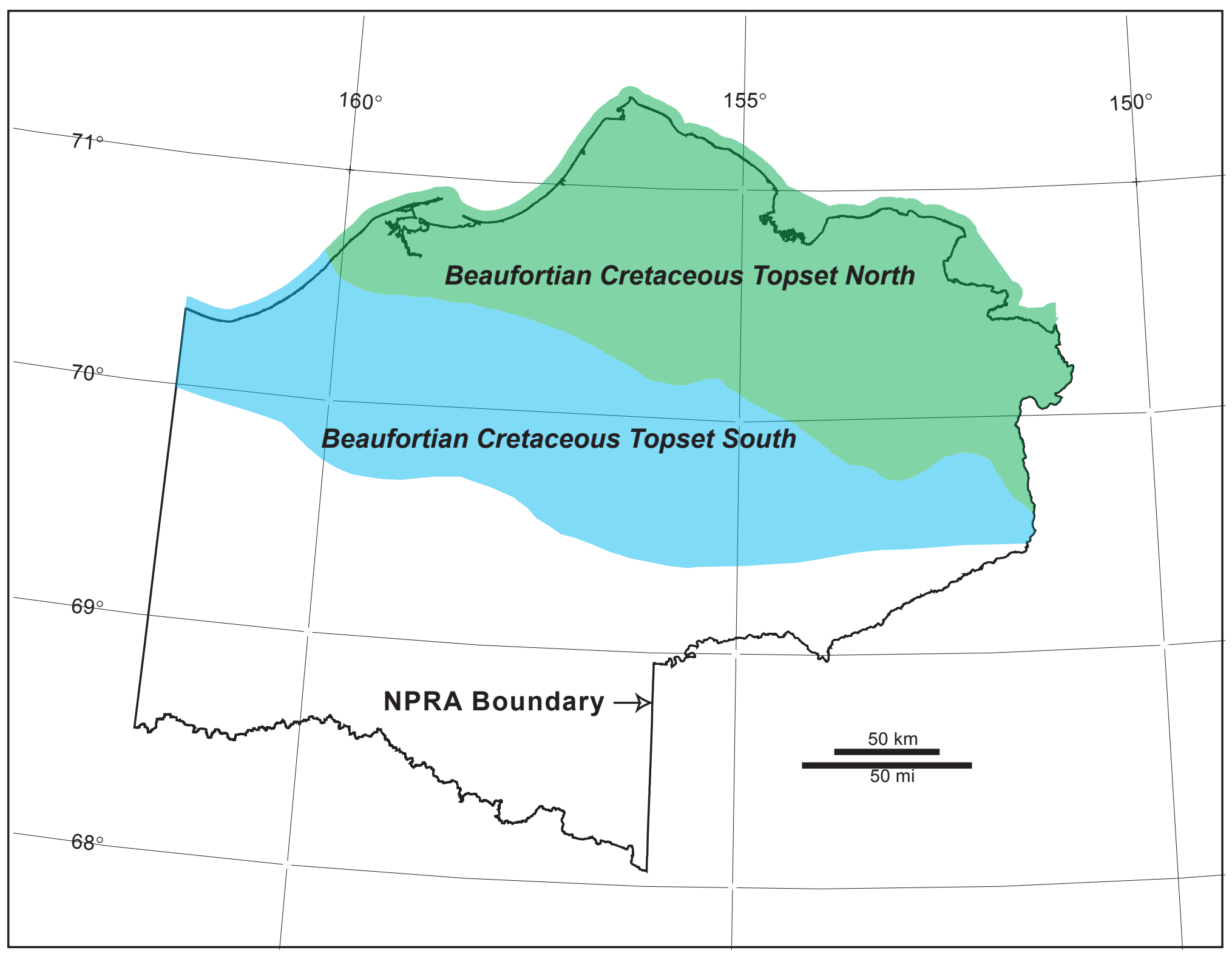

Figure 4. Map showing the areal extent of the two Beaufortian Cretaceous Topset Plays evaluated in the 2002 USGS petroleum resource assessment of the NPRA. 


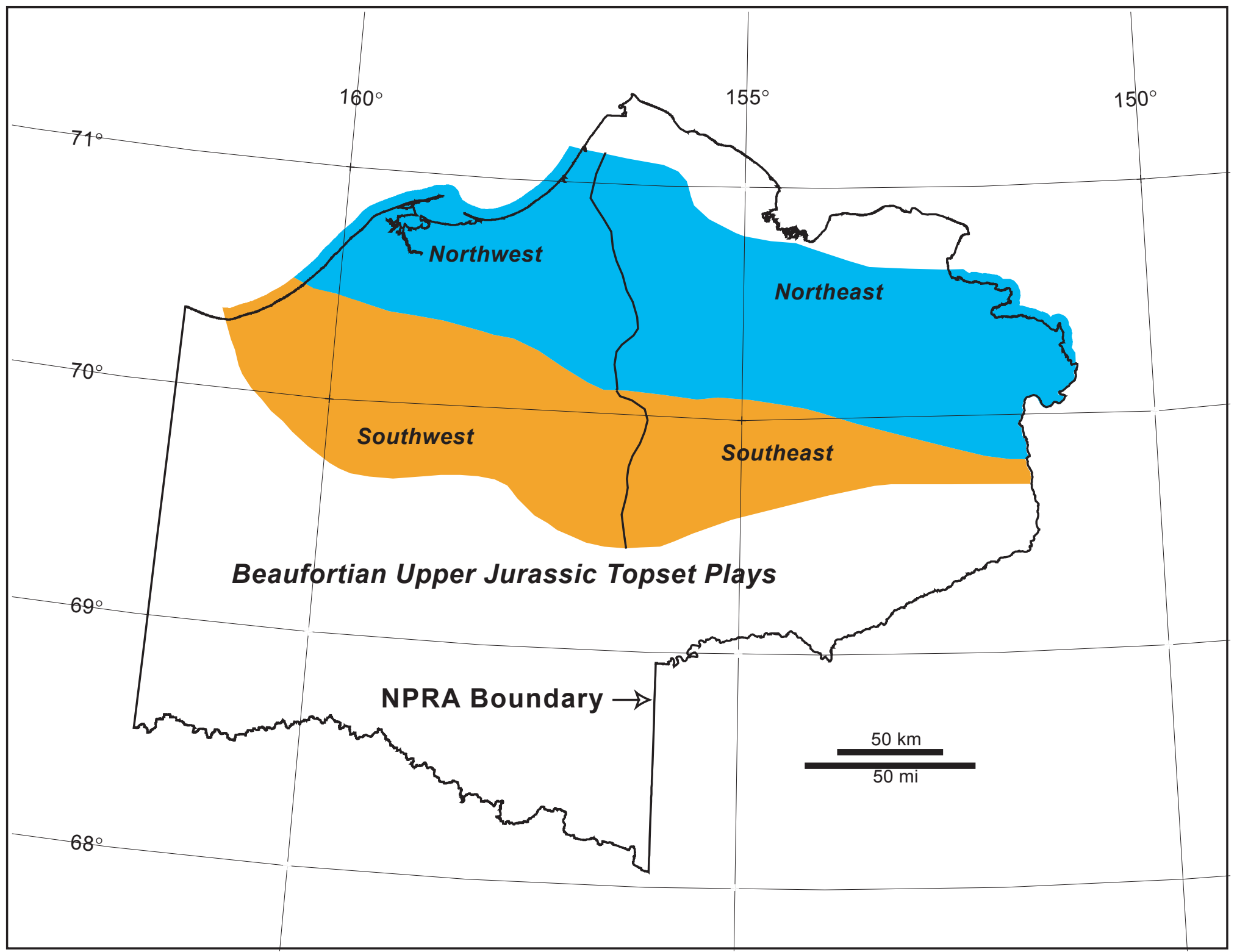

Figure 5. Map showing the areal extent of the four Beaufortian Upper Jurassic Topset Plays evaluated in the 2002 USGS petroleum resource assessment of the NPRA. 


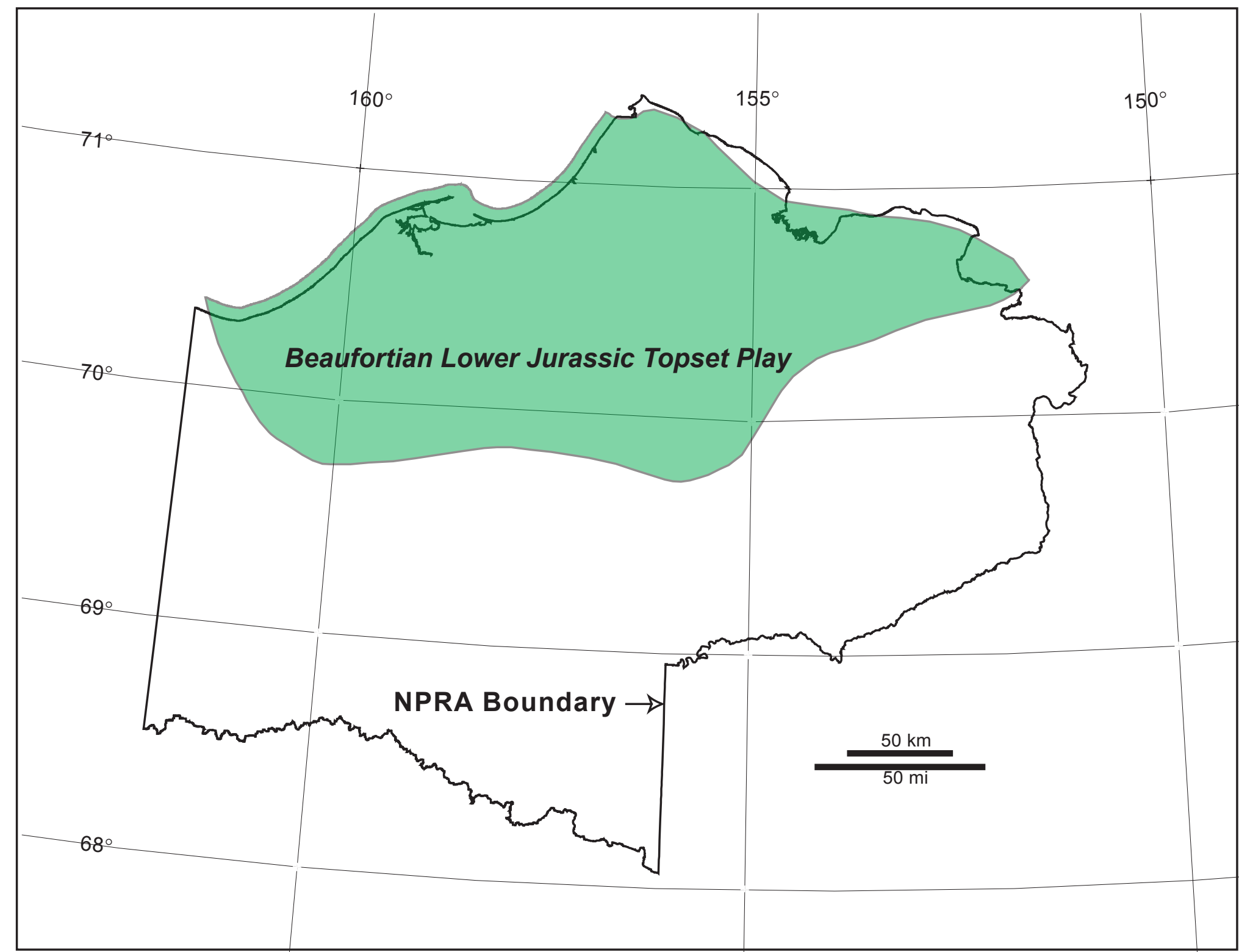

Figure 6. Map showing the areal extent of the Beaufortian Lower Jurassic Topset Play evaluated in the 2002 USGS petroleum resource assessment of the NPRA. 


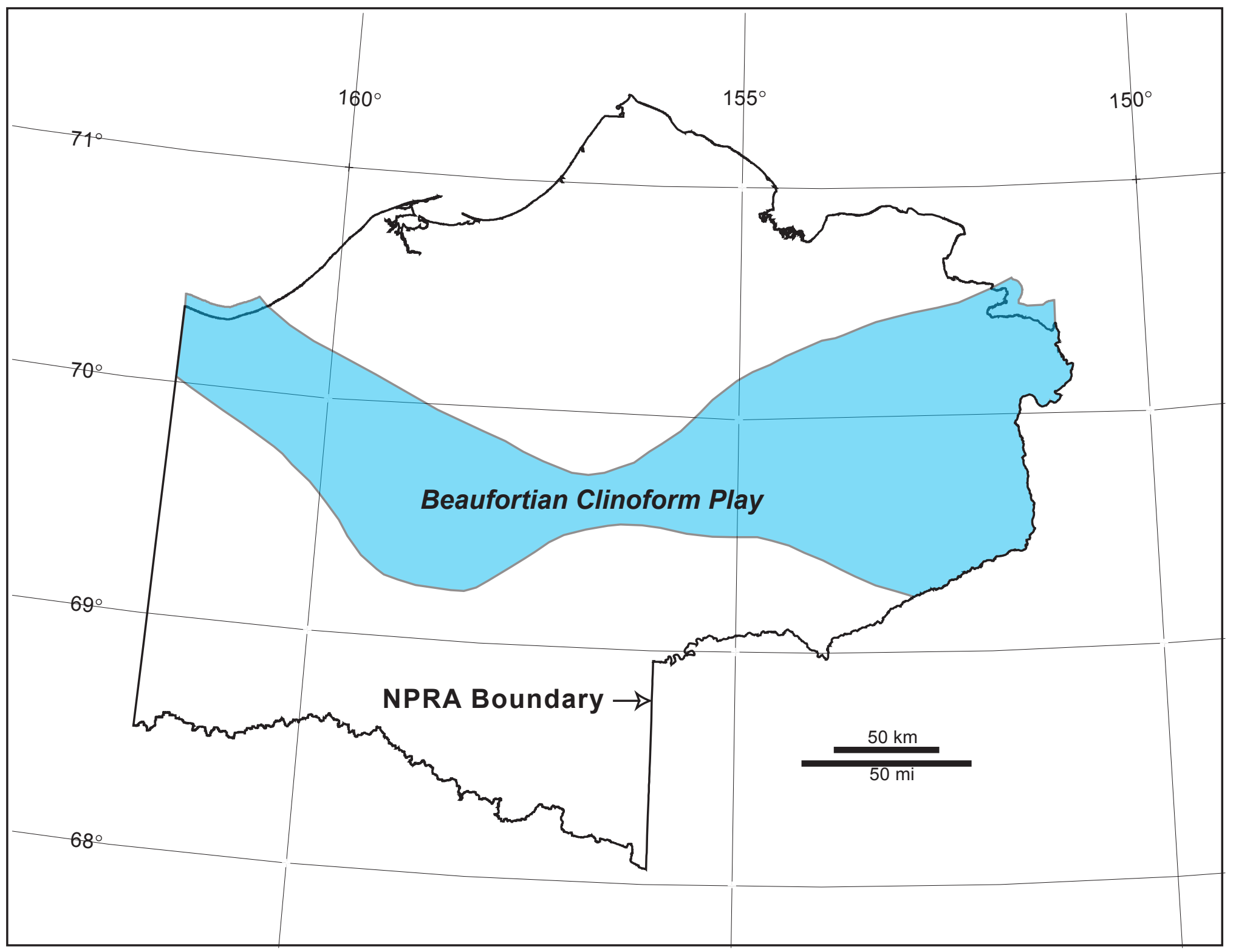

Figure 7. Map showing the areal extent of the Beaufortian Clinoform Play evaluated in the 2002 USGS petroleum resource assessment of the NPRA. 


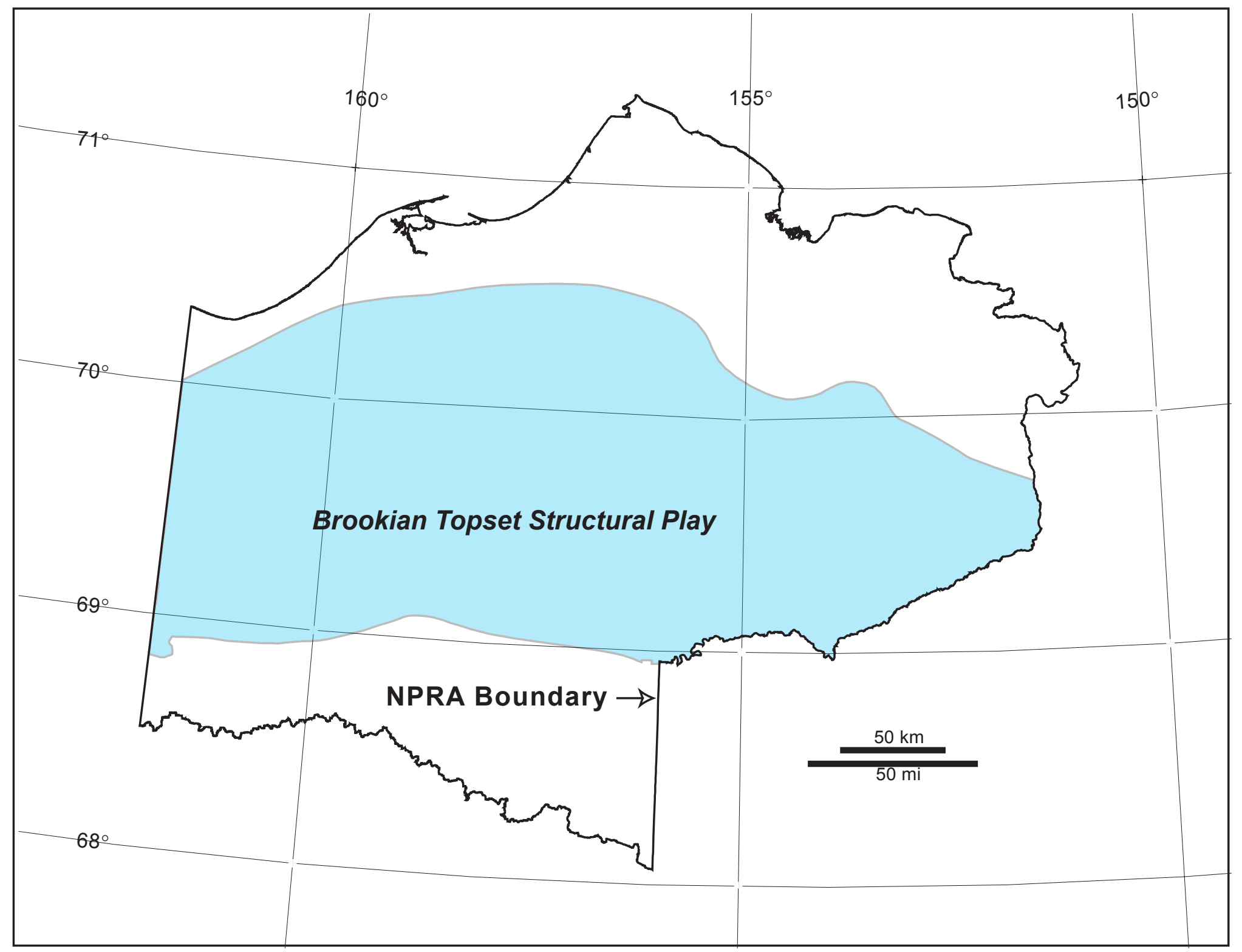

Figure 8. Map showing the areal extent of the Brookian Topset Structural Play evaluated in the 2002 USGS petroleum resource assessment of the NPRA. 


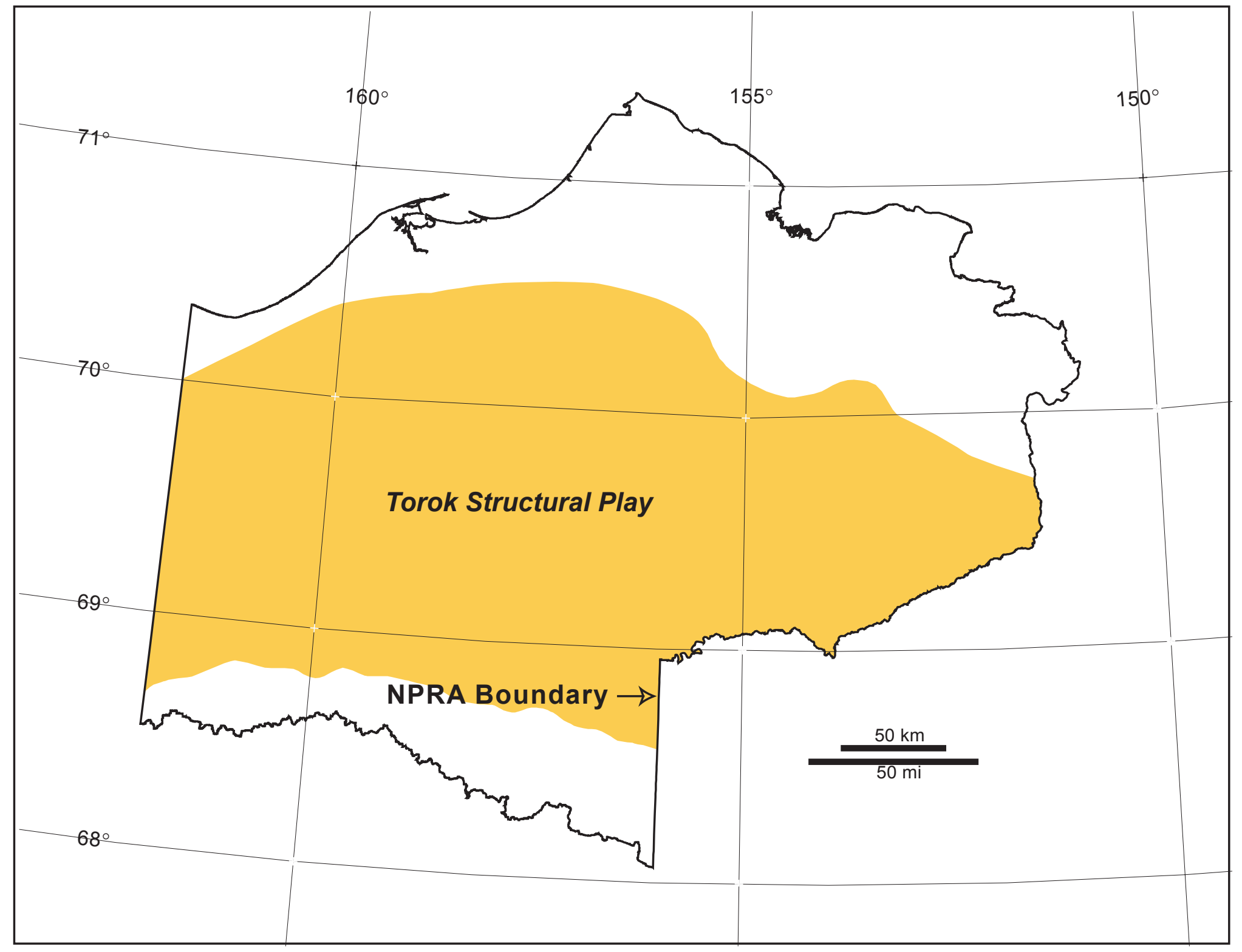

Figure 9. Map showing the areal extent of the Brookian Torok Structural Play evaluated in the 2002 USGS petroleum resource assessment of the NPRA. 


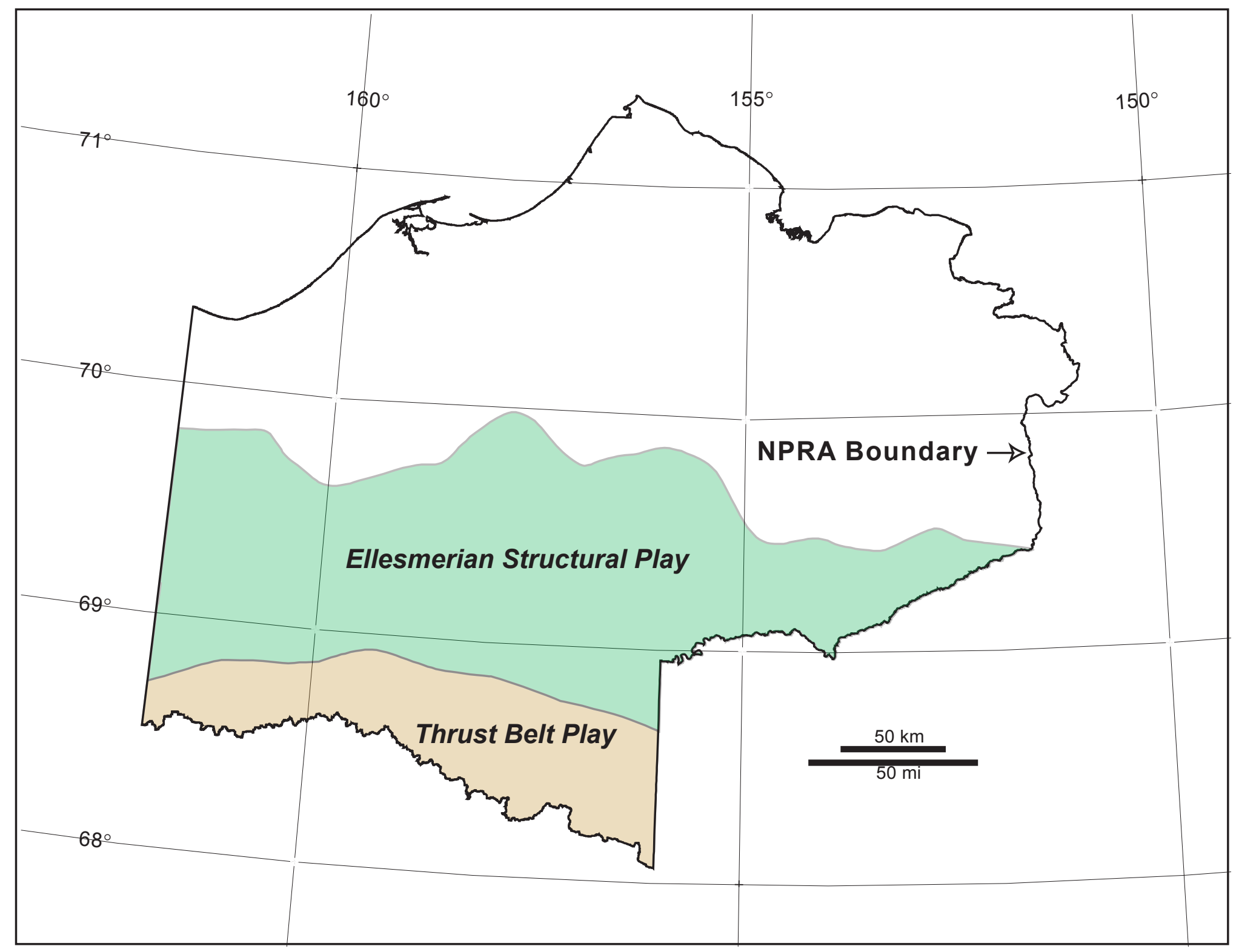

Figure 10. Map showing the areal extent of the Thrust Belt and Ellesmerian Structural Plays evaluated in the 2002 USGS petroleum resource assessment of the NPRA. 


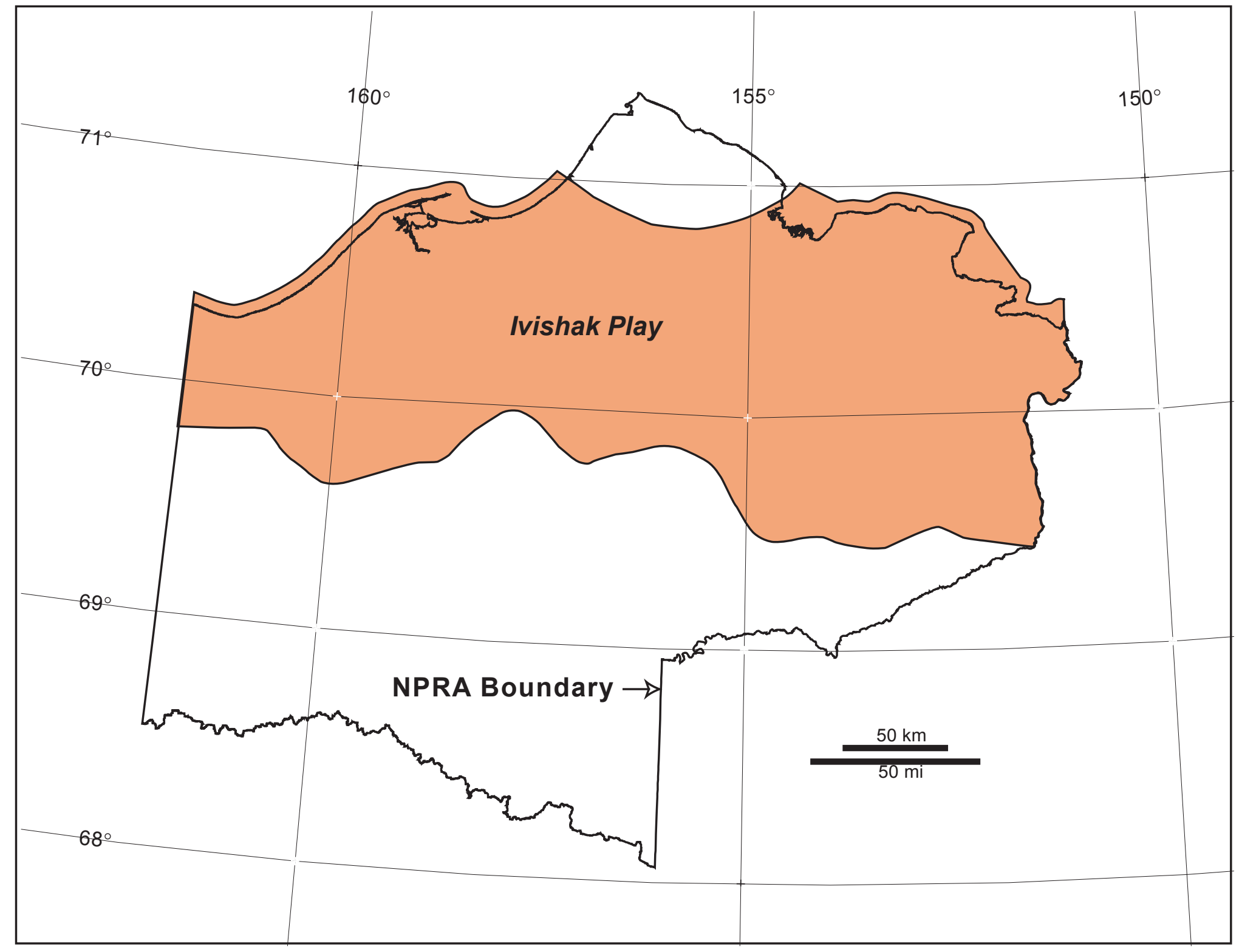

Figure 11. Map showing the areal extent of the Ellesmerian Ivishak Play evaluated in the 2002 USGS petroleum resource assessment of the NPRA. 


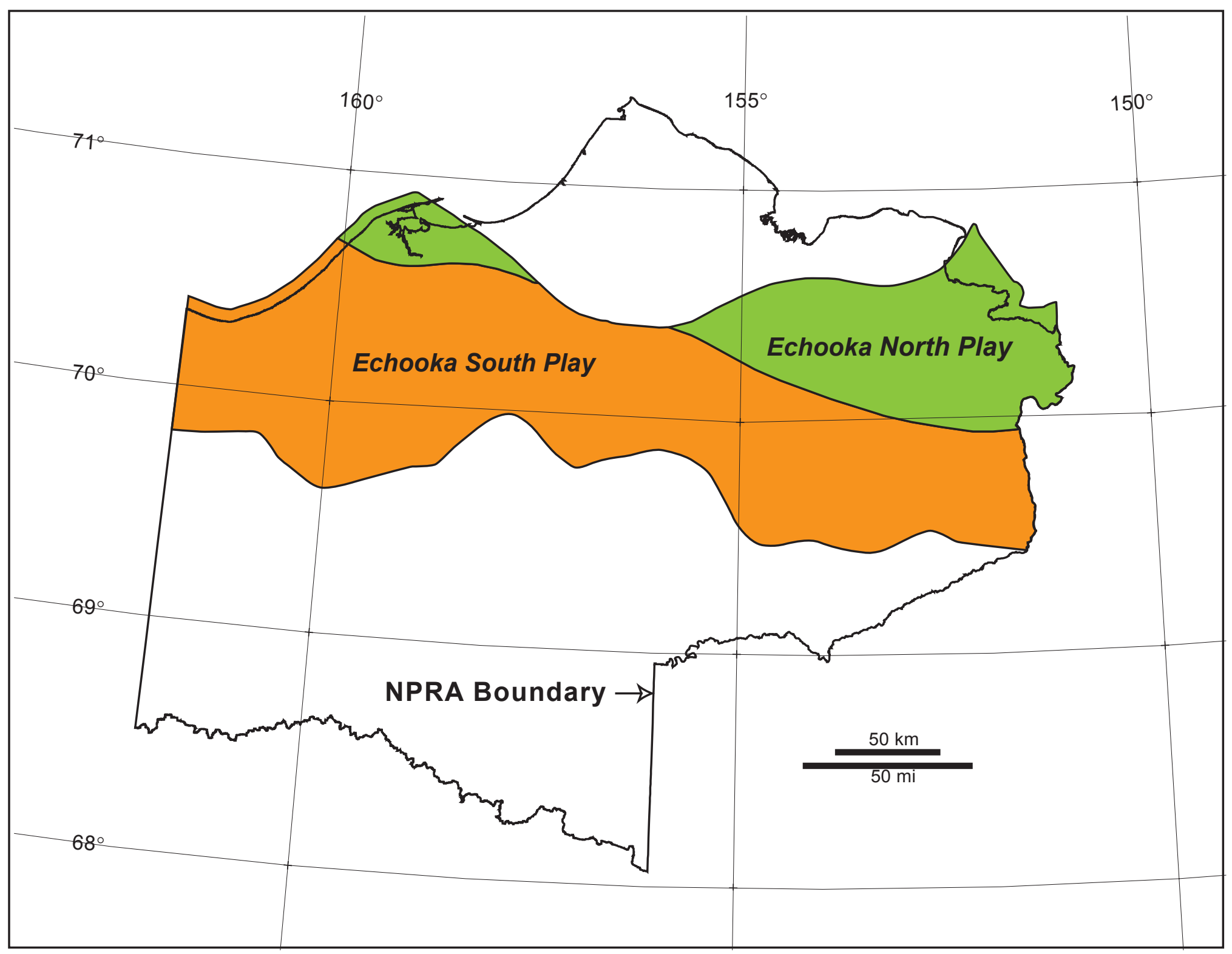

Figure 12. Map showing the areal extent of the Ellesmerian Echooka Plays evaluated in the 2002 USGS petroleum resource assessment of the NPRA. 


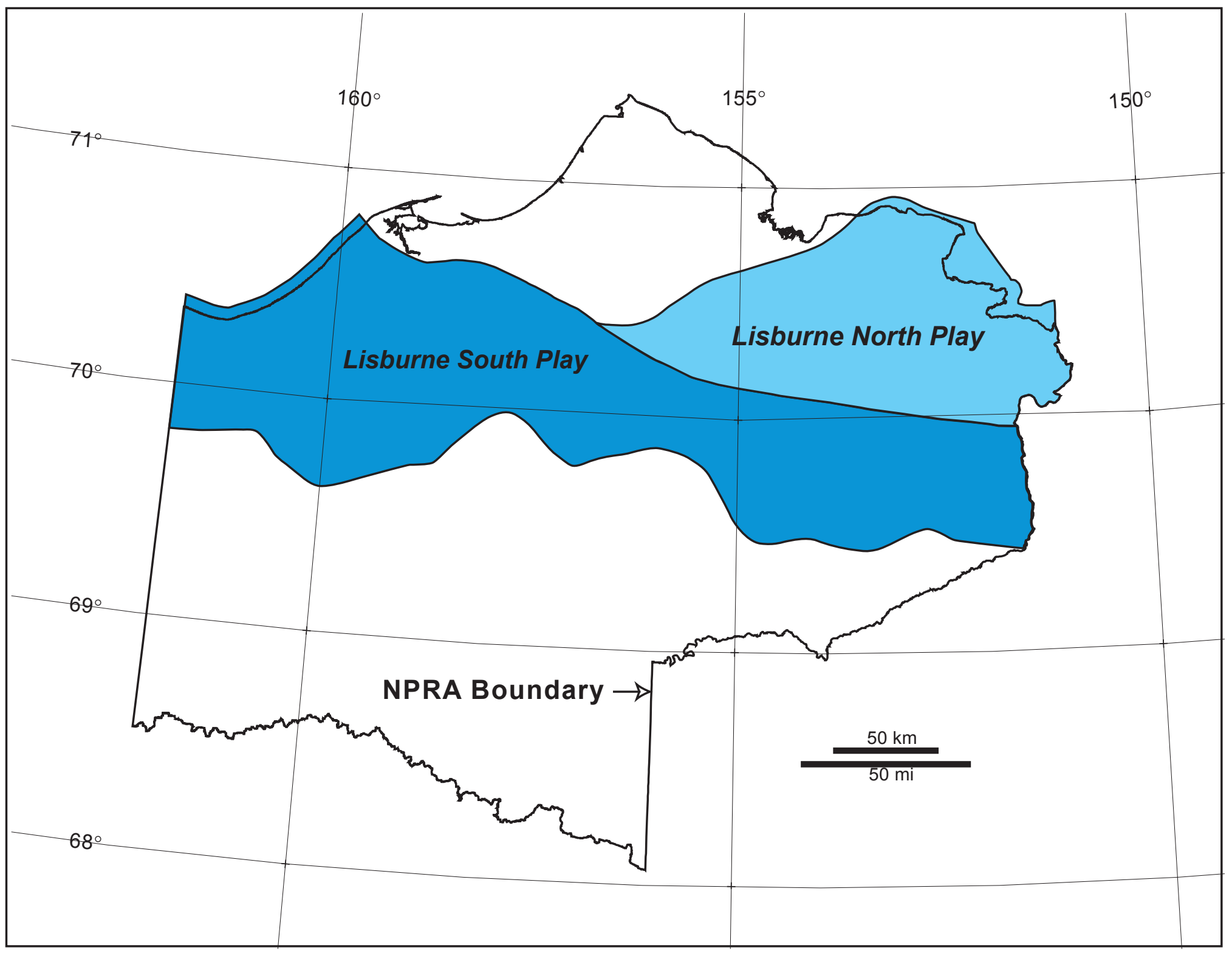

Figure 13. Map showing the areal extent of the Ellesmerian Lisburne Plays evaluated in the 2002 USGS petroleum resource assessment of the NPRA. 


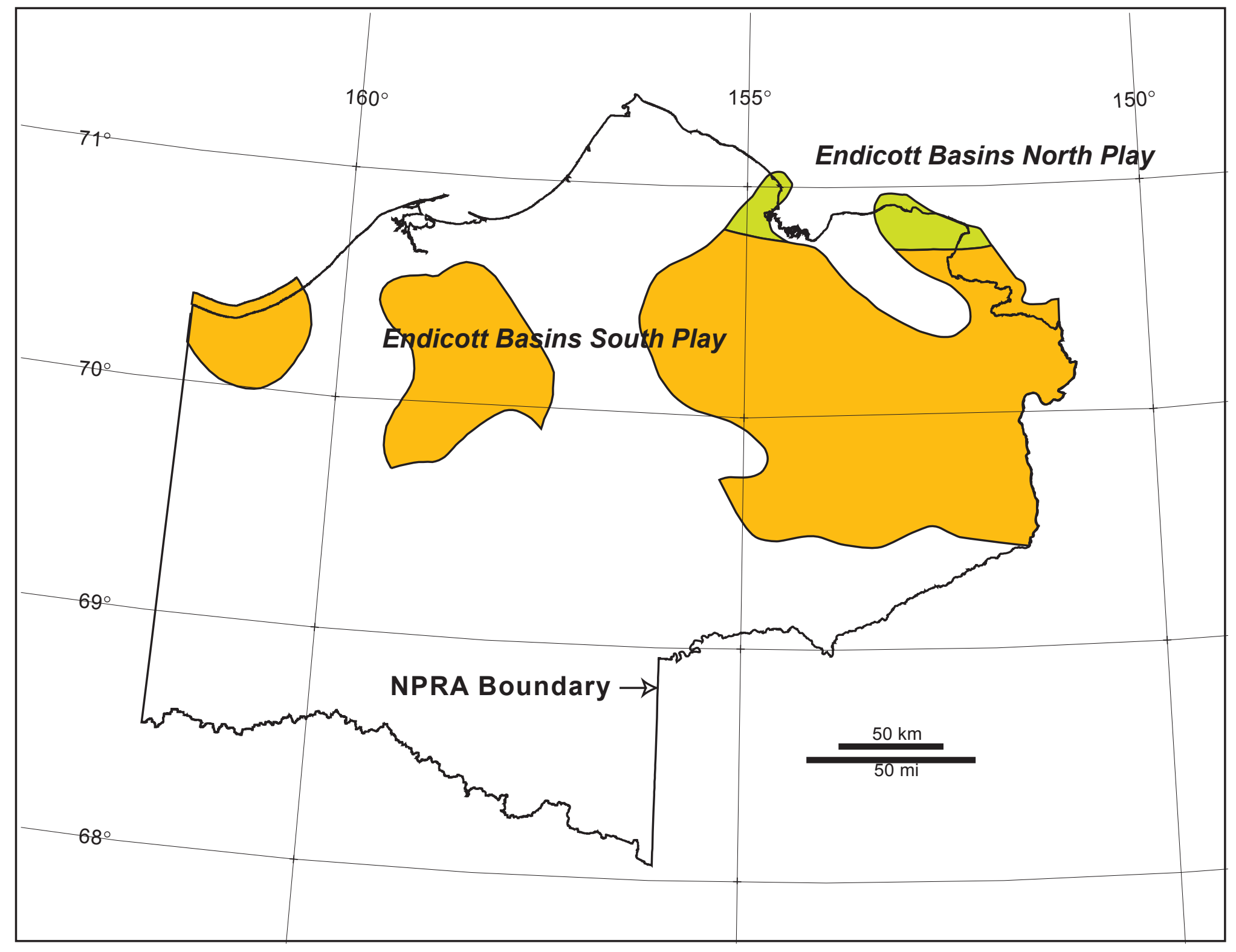

Figure 14. Map showing the areal extent of the Ellesmerian Endicott Basins Plays evaluated in the 2002 USGS petroleum resource assessment of the NPRA. 